\title{
BOUNDARY IDEOLOGEMES OF THE RIGHT-WING RADICALISM IN THE STUDENT'S ENVIRONMENT OF HIGHER EDUCATION INSTITUTIONS IN THE SOUTH OF RUSSIA (on the example of the Rostov region)
}

\author{
(C) Pavel N. Lukichev \\ Southern Federal University, Rostov-on-Don, Russian Federation \\ science-almanac@mail.ru
}

Dynamics of public consciousness is characterized by oscillative motion with periodic leftward shift and rightward shift of ideological and political preferences. At the present time practically in all countries of the world including economically developed there is its shift to the right. In this regard Russia is not an exception. The analysis of collected sociological material shows the prevalence of far-right ideologems of symbols and slogans which being differently understood reflect ideological concepts of ideological and political trends, various by their nature, and the ideological systems corresponding to them that allows to consider them as boundary. Having reasons in far-right ideological concepts they constitute a danger by their attractiveness as get a response among carriers of other political convictions that under the certain circumstances is capable to do them the participants of political actions of far-right and even extremist character. Application of statistical methods of the analysis of results of sociological poll allows constructing the interdependence model of "threats for modern Russia" which were presented in the form of the ideologems characteristic for various ideological systems. The model shows the considerable shift of public consciousness of youth of students of the South of Russia towards the perception of far-right ideological socio-political installations.

Key words: right-wing radicalism, ideological system, nuclear, adjacent, peripheral ideological concepts, ideologems, ideological and political trends, fascist and national socialist views.

\section{[П.Н. Лукичев Пограничные идеологемы правого радикализма в студенческой среде вузов на юге России (на примере Ростовской области)]}

Динамика общественного сознания характеризуется колебательным движением с периодическим полевением и поправением идейно-политических предпочтений. В настоящее время практически во всех странах мира, в том числе и экономически развитых, происходит его сдвиг вправо. Не является в этом отношении исключением и Россия. Анализ собранного социологического материала показывает распространенность праворадикальных идеологем - символов и лозунгов, которые, будучи по разному понимаемыми, отражают идеологические концепты различных по своей природе идейно-политических течений и соответствующих им идеологических систем, что позволяет рассматривать их как пограничные. Имеющие основания в праворадикальных идеологических концептах они представляют опасность своей притягательностью, так как находят отклик среди носителей иных политических убеждений, что при определенных обстоятельствах способно делать их участниками политических акций праворадикального и даже экстремистского характера. Применение статистических методов анализа результатов социологического опроса позволяет построить модель взаимозависимости «угроз для современной России», которые были представлены в виде идеологем, характерных для различных идеологических систем. Модель показывает значительное смещение общественного сознания студенческой молодежи Юга России в сторону восприятия праворадикальных идеологических социально-политических установок.

Ключевые слова: правый радикализм, идеологическая система, ядерные, смежные, периферийные идеологические концепты, идеологемы, идейно-политические течения, фашистские и национал-социалистические воззрения. 
Pavel N. Lukichev - Doctor of sociology science, professor of the department of conflictology and national security of the Southern Federal University. Rostov-on-Don, Russian Federation.

Лукичев Павел Николаевич - доктор социологических наук, профрессор кафредры конфрликтологии и национальной безопасности Южного федерального университета. г. Ростов-на-Дону, Российская Федерация.

The shift to the right of political consciousness became a current problem of the international community today. Almost everywhere, the right-wing parties and groups including taking radical positions became more active. The developed economically countries are not an exception. More than that, they, perhaps, most differ in growth of nationalist sentiments. First of all, it became the reaction of public opinion to the processes of "globalization" as they are carried out under the dictatorship of the USA and the EU [5, $p$. 57]. On the other hand, it became the result of policy of multiculturalism and the influx of migrants with whom the relations on the basis of the current legislation are hard established. However, our country is also not bypassed by trends of ideology of the right-wing radicalism $[4 ; 9]$. That is why it is necessary to research both how far right ideology is widespread in public opinion, and how the views of the people considering themselves representatives of other ideological and political beliefs border with its ideologems and, thereby in the corresponding conditions potentially able to become allies of far-right forces. At the same time studying of public opinion of student youth as advanced, owing to youthful maximalism and not too clear future, the group of any political movement is especially important [1].

The conducted sociological survey allowed to reveal not only the level of prevalence of the right-wing ideology among students of the Rostov region, but also to establish the most significant ideologems of the right-wing radicalism in their public consciousness.

The corresponding social research was conducted in 2015 in the form of questionnaire on the subject "Ukrainian Crisis by Eyes of Student Youth". The title and the general orientation of this research allowed to raise questions and to offer to them responses which revealed both nuclear ideological facilities of far-right currents, and adjacent, peripheral and boundary [3]. Seven hundred and eighteen students of higher education institutions of the Rostov region of the Southern Federal University (SFU), the Don State Technical University (DSTU), the Rostov State Transport University (RSTU), the Rostov academy of national economy and public service (RANEPA), the Don State Agricultural University (DSAU) were involved in the sociological survey. So, in general, on selection the deviation of results of the research does not exceed the following size: $\delta= \pm 3,7 \%$.

Modern methodological approaches to consideration of any ideology assume its representation as a system that, in turn, demands its research in a static and dynamic state.

Studying of an ideological system in its statics means identification of the components of this system and functional relations between them. So, the cognitive constructs anyway receiving verbal presentation and logical, functional relation with each other are the components of ideology as a system. The necessity of logical justification of cognitive constructs provides their interrelation, but this logical relation also has expression in symbols of the ideological system, the used symbolic and slogans representing a quintessence of cognitive constructs and their interrelation [2].

Thus, by consideration of the ideological system in statics it is possible to speak about the existence in it of the main ideological concepts the functional relation between which is steady, so, it sets the structure of the system in general, and the derivatives from them, which are carrying out the role of addition. Respectively verbal and figurative symbols, the nuclear ideologems of any ideological system are the expression of a stable functional 
relation between ideological concepts [10, p. 40-44]. The symbols reflecting the relation of the main concepts with their derivatives and supplements act as the adjacent ideologems.

On the other hand, it is necessary to consider the ideological system in dynamics, in temporal change of its states. Such approach leads to the detection of the ideological concepts remaining invariable in the course of time as well as it leads to the detection of structure-forming relations between these concepts. Their destruction or change leads to the reorganization of the conceptual kernel of the ideological system that represents, in fact, the death of this ideology and its replacing by the other ideological system arising on its fragments. The steady and main concepts of the ideological system keeping themselves and their relations in the course of time are nuclear concepts. Respectively and the ideologems expressing them are also nuclear.

The derivatives from nuclear, supplementing their adjacent concepts receive symbolical expression in adjacent ideologems. However, these concepts are less steady in comparison with nuclear, and their change does not cause the destruction of all ideological system, but only its reforming and improvement according to the changed historical conditions. The adjacent ideologems expressing them also do not differ in stability and can be interchanged by similar in meaning and in spirit symbolical and visual images and verbal formulations.

At last, the dynamics of the ideological system shows the existence of such concepts, which have no stability in the course of time, reacting to the change of the historical situation quickly enough. They are reconsidered, reformulated and have no significant effect on the structure of the ideological system in general. Nevertheless, too frequent change of the periphery loosens the adjacent concepts and, eventually, leads to the revision of the nuclear concepts, therefore, the ideological system perishes. As a result, any ideology is conservative and seeks to prevent any changes, even on its periphery. The concepts that are on the periphery of the system are peripheral for this system, and their relation with adjacent and nuclear concepts is expressed in peripheral ideologems symbolically.

The dynamic approach to the consideration of the ideological system leads to the conclusion about its continuous interaction with other ideologies. Just as the carriers of the ideas are the people, who are in communication with each other so the ideological systems penetrate each other with their concepts inevitably. Under this circumstance, it is necessary to consider the concepts of ideological systems as the crossed and containing the boundary moments [11]. It is characteristic that this marginality is shown first of all at the level of symbolics of ideological concepts that demands the introduction of meaning of boundary ideologems. At the same time, boundary ideologems can arise both on the crossing of nuclear concepts and on the crossing of adjacent and peripheral concepts of different ideological and political trends. Thus, we can say that the kernel of the ideological system can have the crossing with adjacent or peripheral concepts of other ideologies. Adjacent and peripheral concepts of the ideological system can be crossed with nuclear concepts of other ideologies, forming boundary ideologems.

They owing to their brevity and symbolical character can be understood variously depending on their implied content which is dictated by cognitive constructs which can belong, however, even to cardinally various ideologies. For example, the "trident" of Zaporozhian Cossacs which was considered by them as a symbol of trinity of the Holy Trinity, in Judaic numerology where the letter "ש" or number "300" have a sense, is the designation of God as the sum of numerical value of letters in the word God is equal to 300, but the same symbol is used by modern Banderites as the symbolics of "independence" of Ukraine bearing directly Nazi sense like an Aryan swastika in Hitlerite Germany though for ancient Aryans and modern Indians the same swastika is the solar sign. Equally, for example, the slogan "The Earth is to the peasants!" was understood differently by the left 
Socialists-Revolutionaries, Bolsheviks and peasants, but for this reason it was supported by all of them.

However, we meet with certain difficulties during the transition to the sociological interpretation of these philosophical maxims, as we deal not with ideological systems in their statics or dynamics, but with the instant statistics of public opinion. In this case, nuclear, adjacent and peripheral concepts can be investigated only on their symbolical expression in ideologems, as well as the possible crossings of the ideological concepts belonging to the different ideologies expressed in boundary ideologems.

The most suitable method of sociological detection of nuclear, adjacent, peripheral and boundary ideologems, probably, is Z-standardization (the description of the principle is given below). In case of coincidence of the answers of respondents who are the carriers of the studied far-right ideology on revealed, by means of the Z-standardization principle, of typicalness of ideologemes for them, it is possible to say that they are nuclear and they reflect nuclear ideological concepts. Similar in meaning responses noted by those who considered themselves the adherents of far-right ideological and political views respectively can be considered as the adjacent ideologems, characterizing the derivatives from nuclear adjacent concepts. The considerable divergence according to the results of Zstandardization between the responses emphasized by the representatives of the far-right ideological trend acts as an indicator of their periphery in the relation to the concepts of this ideological system. At last, the coincidence characteristic, by the results of application of Zstandardization method, the choice of responses by the representatives of various ideological and political trends shows the marginality of the corresponding ideologems.

The focus of this article is shifted to their detection. At the same time, the matter is not that they represent ideological postulates certain and different from far-right, but that they are the general for the different directions of political thought. Crossings open themselves in such a way that treats the majority of ideologems of the right-wing radicalism with various extent of consent with them.

However, it should be noted the difference of the order of the importance of nuclear ideologems of the right-wing radicalism observed by the results of social research in the consciousness of student youth of the Rostov region, and, probably, of all Russian Federation, from the theoretically emphasized when studying ideologies of fascism and national socialism on the historical material of Europe. The European material puts on the first place in order of importance as the main nuclear ideological construct the paleogenesis mythology containing the idea of revival of the great power which the country was in the historical past [12, p. 26-33]. It acts as the basis for the national consolidation and the nutrient medium of ultranationalism as the second most important ideological construct, generating, in its turn, the idea of the state united nation as an independent organism the interests of which is higher and more important than the interests and freedoms of an individual social person. In public consciousness of respondents the order in order of importance of the ideologems correlated to the ideological constructs expressed by them, is other. The nuclear construct of ultranationalism appeared on the first place while the palingenetic myth was displaced on the second.

However, the nuclear concept of ultranationalism characteristic for the right-wing radicalism is conformable to the perception of environment of representatives of a number of political trends and, first of all, of modern "Bolshevism" (which cannot be identified with the Bolshevism of the beginning of the last century at all). If the Z-standardization methodology [6, p. 33-34] on homebrew fascists and national socialists shows respectively values $Z=1.76$ and $Z=1.94$ concerning the slogan "Russia is only for Russians" on the response "I support completely ", then the adhering ideologies of "Bolshevism" show the deviation exceeding one standard, the size $Z=1.59$. The wider range of adherents of various ideological trends is observed to support any party in the international conflict. The 
response "I will take the part of representatives of my nationality unambiguously" (regardless of the one who is right) was characteristic not only for the called far-right trends (in the same order respectively: $Z=1.65$ and $Z=1.69)$, but also for the national patriots $(Z$ $=1.70)$ and for anarchists $(Z=1.70)[7]$.

In a greater degree the ultranationalism is shown in full consent with the slogan "Beat kikes, save Russia!" which is shown by the fascist and national socialist views as well as by "Bolsheviks" (42.9\% from them; $Z=1.93)$, national patriots $(10.7 \% ; Z=1.66)$, communists $(17 \% ; Z=1.82)$ and anarchists $(11.1 \%$ of $Z=1.25)$. In the greatest measure the ultranationalism is shown by the national patriots that is shown by the response "I completely agree" with the slogan "For Slavic Brotherhood!" which was noted from their number $57.0 \%$, Z-standardization value $(Z=1.60)$ in this case is even above than among the people presenting fascism ideology $(Z=1.16)$ and national socialism $(Z=1.28)$. This result was received during the research. It allows thinking about the process, which is observed today in the country when through media the political power spreads patriotism as nearly a national idea. It turns out so that the growth of patriotic sentiments can objectively promote the simultaneous growth of far-right moods owing to the solidarity of slogan expression of ideologems of different political trends with a nuclear ideologem of ultranationalism.

It occurs that the far-right ideologem of palingenesis has support in the circle of representatives of other political trends of modern Russia.

So, the idea that "Russia was always the empire with the leading role of the Russian nation in it including Great Russians, Little Russians and Belarusians" are approved by the representatives of fascist ideology $(Z=2.70)$ and by anarchists $(27.8 \%$ from them; $Z=$ 1.24). The responses, competitive with it, "Russia always was and has to remain a multinational imperial civilization with the leading role of Orthodoxy and the Russian culture in it" and "Russia was, is and will be the great Eurasian power with the geopolitical interests" were characteristic respectively for "Bolsheviks" (42.9\% from them; $Z=1.07)$ and for already mentioned anarchists $(27.8 \%$ from them; $Z=1.46)$. As for the slogan "Russia has to be the Empire!", it is conformable (the response is "I completely agree") to political moods of "Bolsheviks" (57.1\% from them; $Z=1.42)$ and of national patriots ( $46.3 \%$ from them; $Z=1.56)$. At the same time to some extent (the response is "there is something in it") the recognition of this slogan is characteristic even for the people representing conservative political moods ( $29.7 \%$ from carrying themselves to it; $Z=1.18)$.

The third nuclear ideologem connected with the idea of the small importance of the individual and the advantage of the nation, noted by the slogan "Nation is everything, Individual is nothing!" has numerous adherents among conservatives $(6.1 \%$ from them; $Z=$ $1.61)$, socialists $(6.9 \%$ from them; $Z=1.13)$, anarchists $(11.1 \%$ from them; $Z=1.50)$ and considering themselves monarchists $(7.0 \%$ from them; $Z=1.24)$. Thereby, among allies of the right radicals it is necessary to count carriers of views of "Bolsheviks" and anarchists and also, on a number of positions, of national patriots, communists and socialists, conservatives and monarchists.

Adjacent far-right ideologems are also conformable to thoughts and feelings of the representatives of various ideological and political trends.

So, the slogan "The place of woman is in the kitchen, but is not in policy!" is completely supported, first of all, by those who consider themselves socialists (18.4\% from them; $Z=1.88$ ), and by "Bolsheviks" (28.6\% from them; $Z=1.02)$.and, thereby, they show the sexist masculine moods which are the sign of the right-wing radicalism. The slogan "There is somthing in it" is supported by the representatives of communistic ideology (28.3\% from them; $Z=1.35)$, by conservatives (26.7\% from them; $Z=1.23$ ) and to some extent by monarchists $(26.3 \%$ from them; $Z=1.09)$. The masculine installations are also shown in the response on the idea of an image of the real man "who with deadly force protects freedom 
of the people ..." And again the far-right moods are closed up with left-wing radical as this response is the most characterizing views of "Bolsheviks" $(71.4 \%$ from them; $Z=1.46)$. The response for the question about the means of upholding of the interests $(57.1 \%$ from them; $Z=2.62$ ) "it is necessary to fight for the interests by all means including weapon in the arms" will be characteristic for them.

During the research of nuclear ideologems it was learnt that there was a shift of theoretically peripheral ideologem of idolization of the strong personality (our right radicals A.P. Barkashov and A. Merkel) towards adjacent with a block of nuclear ideologems. The first naturally attracts besides right radicals "Bolsheviks" (14.3\% from them; $Z=1.63)$. Being a figure of the left-wing radicalism, he is supported by the left radicals. However, on the extremist political actions he is close to the idea of the identity of the leader characteristic and for the right radicals. In other words, he is close, in general, to the radical moods. The second attracts sympathies of liberals $(26.5 \%$ from them; $Z=1.23)$. The fact that they were solidary in the sympathies for this personality with the right radicals is not accidentally as this personality bears the scale of contradictions. Her image of the leader of the liberal Europe and the protector of the liberal values of advanced modern "democracy" is combined with real processes of strengthening of a role of Germany in the European Union and personal dictatorship of A. Merkel among the European statesmen. At the same time liberal values are, in fact, closed up with ideology of extremist radical actions, in particular in relation to Russia when the western liberals openly support terrorists and Nazi feeble efforts in a number of the countries of Europe under the slogans of fight against the Russian threat.

The adjacent with nuclear far-right ideologem of anti-elitism is general for a lot of political trends. So, the slogan "Down with Oligarchs!" is conformable to the moods of communistic youth, $39.6 \%(Z=1.71)$ of respondents completely agree with it while among national socialists full consent with it was expressed by $33.3 \%(Z=1.55)$ and also by the student youth having anarchical ideological and political beliefs $(27.8 \%$ from them; $Z=$ 1.11). However, the response "There is something in it" was not an alien to the considerable part of conservatives $(42.4 \%$ from them; $Z=1.58)$ and in a bigger measure to "Bolsheviks" (71.4\% from them; $Z=1.53)$.

The same can be also told about the attitude towards the liberalism associated with "the fifth column" of a political fan of modern Russia. The slogan "Down with the Fifth Column!" is completely supported by the fourth part of far-right national socialists $(25.9 \%$ from them; $Z=1.25)$ and even in a bigger measure by "Bolsheviks" $(42.9 \%$ from them; $Z=$ $1.76)$, by national patriots $(21.5 \%$ from them; $Z=1.33)$, by communists $(24.5 \%$ from them; $Z$ $=1.15$ ), and, at last, the solidarity with it is expressed by the fifth part of conservativeminded respondents $(20.6 \%$ from them; $Z=1.05)$. "There is something in it" is also supported by socialists $(21.8 \%$ from them; $Z=1.69)$.

The peripheral ideologem of the right radicalism at the moment of historical time is the relation to "Maidan" which owing to the periphery differentiates the right radicals in accents and estimates of the Ukrainian events in the course and after the commission of the rebellion in 2014.

So, the assessment of "Maidan" as a project of intelligence agencies of the USA and the EU pursuing their aims coincides among the adhering national socialist ideological and political views $(63.0 \%$ from them; $Z=1.57$ ) and among the supporters of communistic ideology $(56.6 \%$ from them; $Z=1.02)$. At the same time the readiness for active participation in the movement "Anti-Maidan" along with carriers of national socialist ideology $(Z=1.31)$ was shown by the same "Bolsheviks" ( $28.6 \%$ from them; $Z=1.88)$. On the other hand, as well as in many other cases, anarchists (38.9\% from them; $Z=2.47$ ) are solidary with the most characteristic for the representatives of the national socialist response "it is justified that the rebels of Donbass took up arms, otherwise, the number of victims and refugees would be even more". 
On ideological and political views it is possible to recreate some unity of ideas of threats of the national security which take place in relation to modern Russia and are the index showing the degree of community and crossing of ideologems of different political trends (Table 1). In this case the most effective methodology is the regression analysis which on positive or negative value of coefficients of the equation of linear regression allows to speak about the influence upon each other of the variables $\mathbf{x}$ and $\hat{y}$ [8, p. 79-80]:

\section{$\hat{y}=a+b x$,}

where $\hat{y}$ is a calculated value of a variable $\boldsymbol{y}$;

$\boldsymbol{x}$ is an observed value of a variable $\boldsymbol{x}$;

$\boldsymbol{a}$ and $\boldsymbol{b}$ are coefficients of the linear regression.

At the same time the positive value of coefficient a shows that $\mathbf{x}$ is a dependent variable, as it receives the existence from a particular level of a variable $\mathbf{y}$. On the contrary, the negative value of the coefficient a points to the dependence of a variable $\mathbf{y}$ from $\mathbf{a}$ variable $\mathbf{x}$, because neither $\mathbf{x}$ nor $\mathbf{y}$ can have the negative values.

According to the Table 1 the values of coefficients of correlation $\mathbf{r}_{x y}$ between the columns and the regression coefficients $\mathbf{a}$ and $\mathbf{b}$ (Table 2) are calculated. The result of the regression analysis is the column of interinfluence of variables (Fig. 1).

Table 1

The ideological and political convictions and ideas of threats for modern Russia (in the percentage representation columnwise)

\begin{tabular}{|c|c|c|c|c|c|c|c|c|c|c|c|}
\hline \multirow{2}{*}{$\begin{array}{l}\text { What, in your } \\
\text { opinion, threatens } \\
\text { Russia most of all } \\
\text { at present? }\end{array}$} & \multicolumn{11}{|c|}{ How would you characterize your ideological and political convictions? } \\
\hline & 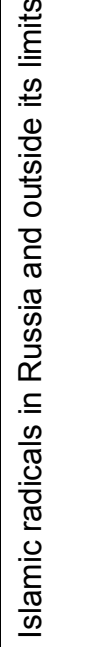 & 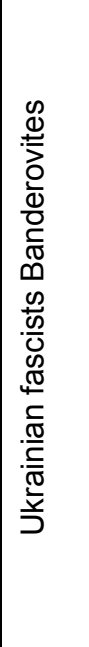 & 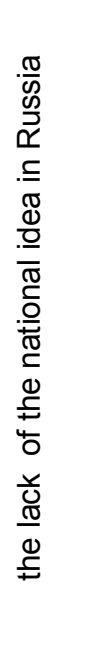 & 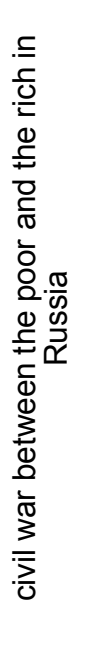 & 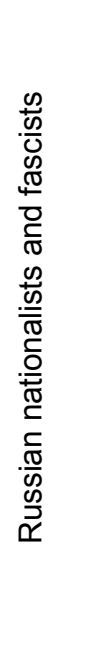 & 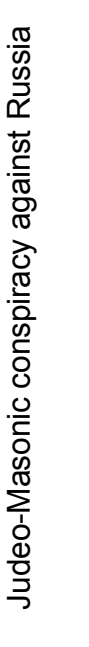 & 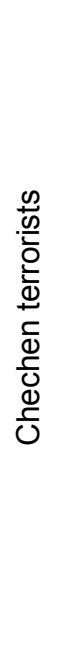 & 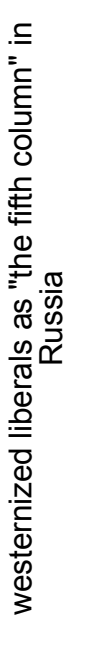 & 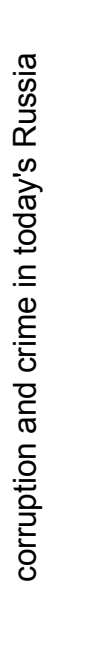 & $\begin{array}{l}\bar{\Xi} \\
\overline{\mathbf{t}}\end{array}$ & 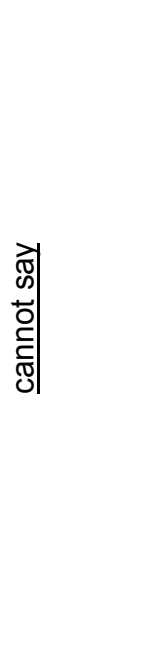 \\
\hline conservative & 15,6 & 18,7 & 18,2 & 21,1 & 16,7 & 24,6 & 18,8 & 24,6 & 15,0 & 22,4 & 12,1 \\
\hline liberal-minded & 25,3 & 22,2 & 23,1 & 22,5 & 21,9 & 7,2 & 25,0 & 15,1 & 26,5 & 17,2 & 13,2 \\
\hline bolshevistic & 0,5 & 1,5 & 0,8 & 0,0 & 0,9 & 1,5 & 2,1 & 0,0 & 0,2 & 1,7 & 1,1 \\
\hline national and patriotic & 15,6 & 13,8 & 11,6 & 11,3 & 14,9 & 17,4 & 10,4 & 17,5 & 12,2 & 5,2 & 7,7 \\
\hline fascist & 0,5 & 0,0 & 1,6 & 1,4 & 1,8 & 4,3 & 2,1 & 0,0 & 0,0 & 0,0 & 1,1 \\
\hline national socialist & 5,1 & 4,4 & 3,3 & 4,2 & 0,0 & 4,3 & 4,2 & 0,8 & 2,8 & 0,0 & 0,0 \\
\hline communistic & 5,1 & 3,9 & 5,0 & 5,6 & 5,3 & 5,8 & 7,3 & 6,3 & 5,0 & 7,0 & 6,6 \\
\hline socialist & 5,1 & 11,8 & 7,4 & 14,1 & 9,6 & 8,8 & 12,5 & 9,5 & 7,5 & 17,2 & 6,6 \\
\hline anarchical & 1,4 & 0,0 & 5,0 & 0,0 & 1,8 & 5,8 & 1,0 & 0,8 & 3,0 & 1,7 & 1,1 \\
\hline monarchic & 6,9 & 3,9 & 12,4 & 2,8 & 7,9 & 7,2 & 2,1 & 9,5 & 6,0 & 6,9 & 2,2 \\
\hline other & 3,7 & 1,5 & 2,5 & 1,4 & 1,8 & 1,5 & 0,0 & 3,2 & 2,5 & 6,9 & 1,1 \\
\hline cannot say & 15,2 & 18,3 & 9,1 & 15,6 & 17,4 & 11,6 & 14,5 & 12,7 & 19,3 & 13,8 & 47,2 \\
\hline Grand total & 100 & 100 & 100 & 100 & 100 & 100 & 100 & 100 & 100 & 100 & 100 \\
\hline
\end{tabular}


For the purpose of reduction of a number of connections during the drawing up of a graph of dependences we will introduce the restriction determined by the significance value $\alpha=0.001$, in other words by the reliability level $\mathbf{y}=0.999$ for the transferring of the received result to the general totality. In this case for consideration there are only values of correlation $\mathbf{r}>0.872$ that is defined by the tabular value of $t$-distribution of $\mathbf{t}=5.041$ on which we receive the smallest considered level of correlation connection:

$$
r=t \sqrt{\frac{1}{n-2+t^{2}}} .
$$

Table 2

The table of values of coefficients of correlation and coefficients of regression

\begin{tabular}{|c|c|c|c|c|c|c|c|}
\hline$r_{12}=0,93$ & $r_{13}=0,91$ & $r_{14}=0,89$ & $r_{15}=0,95$ & $r_{16}=0,59$ & $r_{17}=0,90$ & $r_{18}=0,82$ & $r_{19}=0,97$ \\
\hline$a=0,213$ & $a=1,61$ & $a=0,509$ & $a=0,589$ & $\mathrm{a}=4,044$ & $a=0,636$ & $a=1,309$ & $a=-0,269$ \\
\hline \multirow[t]{22}{*}{$\mathrm{b}=0,974$} & $\mathrm{~b}=0,807$ & $\mathrm{~b}=0,939$ & $\mathrm{~b}=0,929$ & $\mathrm{~b}=0,515$ & $\mathrm{~b}=0,924$ & $\mathrm{~b}=0,843$ & $\mathrm{~b}=1,032$ \\
\hline & $\mathrm{r}_{23}=0,84$ & $\mathrm{r}_{24}=0,98$ & $\mathrm{r}_{25}=0,962$ & $\mathrm{r}_{26}=0,69$ & $\mathrm{r}_{27}=0,96$ & $r_{28}=0,87$ & $\mathrm{r}_{29}=0,95$ \\
\hline & $a=2,369$ & $a=-0,071$ & $\mathrm{a}=0,802$ & $a=3,562$ & $\mathrm{a}=0,460$ & $a=1,261$ & $a=0,266$ \\
\hline & $\mathrm{b}=0,716$ & $\mathrm{~b}=0,992$ & $\mathrm{~b}=0,903$ & $\mathrm{~b}=0,573$ & $\mathrm{~b}=0,945$ & $\mathrm{~b}=0,849$ & $\mathrm{~b}=0,968$ \\
\hline & & $r_{34}=0,84$ & $r_{35}=0,89$ & $r_{36}=0,64$ & $r_{37}=0,85$ & $r_{38}=0,85$ & $r_{39}=0,88$ \\
\hline & & $a=-0,038$ & $\mathrm{a}=0,118$ & $a=3,177$ & $a=0,156$ & $a=0,185$ & $a=-0,423$ \\
\hline & & $\mathrm{b}=1,005$ & $\mathrm{~b}=0,986$ & $\mathrm{~b}=0,619$ & $\mathrm{~b}=0,981$ & $\mathrm{~b}=0,978$ & $\mathrm{~b}=1,051$ \\
\hline & & & $r_{45}=0,93$ & $r_{46}=0,70$ & $r_{47}=0,98$ & $r_{48}=0,86$ & $r_{49}=0,91$ \\
\hline & & & $a=1,168$ & $a=3,568$ & $a=0,396$ & $\mathrm{a}=1,377$ & $a=0,719$ \\
\hline & & & $\mathrm{b}=0,860$ & $\mathrm{~b}=0,572$ & $\mathrm{~b}=0,952$ & $\mathrm{~b}=0,835$ & $\mathrm{~b}=0,914$ \\
\hline & & & & $r_{56}=0,69$ & $r_{57}=0,92$ & $r_{58}=0,89$ & $r_{59}=0,96$ \\
\hline & & & & $\mathrm{a}=3,272$ & $a=0,324$ & $a=0,601$ & $a=-0,362$ \\
\hline & & & & $\mathrm{b}=0,607$ & $\mathrm{~b}=0,961$ & $\mathrm{~b}=0,928$ & $\mathrm{~b}=1,043$ \\
\hline & & & & & $r_{67}=0,61$ & $r_{68}=0,90$ & $r_{69}=0,54$ \\
\hline & & & & & $a=2,291$ & $a=-0,580$ & $a=2,751$ \\
\hline & & & & & $\mathrm{b}=0,725$ & $\mathrm{~b}=1,070$ & $\mathrm{~b}=0,670$ \\
\hline & & & & & & $r_{78}=0,80$ & $r_{79}=0,93$ \\
\hline & & & & & & $a=1,694$ & $a=0,343$ \\
\hline & & & & & & $\mathrm{b}=0,797$ & $\mathrm{~b}=0,959$ \\
\hline & & & & & & & $r_{89}=0,78$ \\
\hline & & & & & & & $a=1,577$ \\
\hline & & & & & & & $\mathrm{b}=0,811$ \\
\hline
\end{tabular}

The starting moments with a significance value $\alpha=0.001$ are the sixth position (Judeo-Masonic conspiracy). In a certain measure these points are the third position (the lack of the national idea) and the seventh position (Chechen terrorists). The central moments are the eighth (westernized liberals as "the fifth column" in Russia), the ninth (corruption and crime), the fifth (Russian nationalists and fascists) and the fourth (civil war between the poor and the rich). The terminal moments are the first position (Islamic radicals) and the second position (Ukrainian fascists Banderovites). 


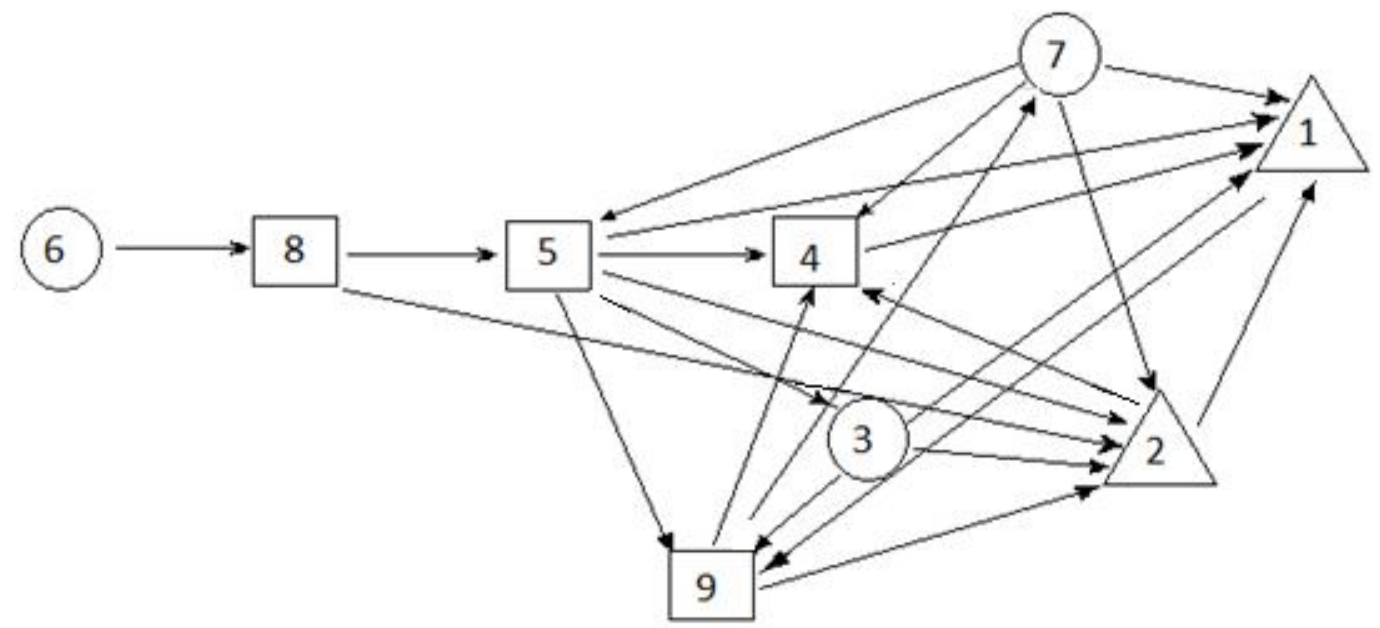

Figure 1. The graph of interinfluences of variables:

1. Islamic radicals in Russia and outside its limits;

2. Ukrainian fascists Banderovites;

3. The lack of the national idea in Russia;

4. Civil war between the poor and the rich in Russia;

5. Russian nationalists and fascists;

6. Judeo-Masonic conspiracy against Russia;

7. Chechen terrorists;

8. Westernized liberals as "the fifth column" in Russia;

9. Corruption and crime in modern Russia.

Thus, it is remarkable that the fact that the point of view, general for the all respondents, on the initial factor of threats for modern Russia, irrespective of the taken political position, is, in fact, far-right. It comes laden with a sign of ultranationalistic installation, besides having a mystically fantastic cover of "Judeo-Masonic conspiracy" from which the derivatives of all other threats appear. It forces to conclude about the existence of strong latent influence of ideologems of the right-wing radicalism on the public consciousness of student youth of the South of Russia, which under the certain conditions can give a considerable layer of allies to anti-Zionist slogans and actions. At the same time through the coefficient of determination of Pearson, the density of connection between the idea of "Judeo-Masonic conspiracy" as a threat to modern Russia and a threat proceeding from "westernized liberals as "the fifth column"' is established. Its size is $\mathbf{r}^{2}=0.87$. In other words in $87 \%$ of cases the dependence between these representations is such that a threat in the form of "westernized liberals" is a derivative in public opinion from the idea of "JudeoMasonic conspiracy". If to consider the hatred to the liberals from the right radicals as an ideologem, then it turns out, that the illiberalism in public opinion (87\% of the respondents) representing various political trends is conformable to the right-wing radicalism.

The fact that "the lack of the national idea" in a certain measure is a starting moment in this graph of interinfluences is defined by the impact on this phenomenon in public opinion of the fifth position ("Russian nationalists and fascists"), i.e. just by right radicals who in this regard act as a threat for modern Russia and an obstacle to the existence of the Russian national idea. In turn, this threat as it is represented to the public opinion, influences such phenomena as "Islamic radicals in Russia and outside its limits" and "corruption and crime in today's Russia". In the first case the connection of variables has density equal to $r^{2}=0.83$, and in the second case $r^{2}=0.77$. At last, the positive value of coefficient of $\mathbf{b}$ of the regression equation indicates the positive connection, i.e. the increase of numerical representation of the fifth position ("Russian nationalists and fascists) 
increases the value of the third position ("lack of the national idea"), i.e. aggravates the fact of lack of the national idea that in turn leads to the increase of the ninth position ("corruption and crime in modern Russia") and of the first position ("Islamic radicals in Russia and outside its limits").

The limitation as a starting moment of the seventh position ("Chechen terrorists") is connected with impact of the ninth position on it ("corruption and crime in today's Russia"). The connection density in this case is equal to $r^{2}=0.865$. I.e. $86.5 \%$ of respondents consider that the presence of "Chechen terrorists" and the threat proceeding from them for the Russian statehood are the derivatives from the level of corruption of administrative and law-enforcement structures of Russia.

At the same time the first position ("Islamic radicals in Russia and outside its limits"), the ninth position ("corruption and crime in today's Russia") and the seventh position ("Chechen terrorists") are connected by the circular motion, i.e. one generates and strengthens another (the coefficient of regression of $\mathbf{b}>0$ ).

The circular motions with mutual positive influence (i.e. mutually strengthen or mutually weaken each other) also connect the ninth position ("corruption and crime"), the fourth ("civil war between the poor and the rich in Russia") and the first ("Islamic radicals in Russia and outside its limits"); and also the ninth ("corruption and crime"), the seventh ("Chechen terrorists") and the fifth ("Russian nationalists and fascists"). In the latter case there is a characteristic for the public opinion of a contradiction in assessment of "Russian nationalists and fascists" as the threatening to the Russian statehood and solidarity with farright nuclear and adjacent ideologems of Russian fascists and national socialists.

The terminal moment in the system of interinfluences with some share of limitation can be considered the fourth position ("civil war between the poor and the rich in Russia"). In other words, this position focuses on itself the influence of all other alleged threats for the national security. The limitation is connected with the fact that this position makes an impact on the first phenomenon ("Islamic radicals in Russia and outside its limits"), and this influence has a character of direct dependence, thus, the increase of one leads to the increase of another and vice versa. I.e. the public opinion connects by the direct dependence the strengthening of a social and economic gap between "the rich" and "the poor" and of the conflict determined by injustice of distribution of material benefits with the growth of danger of Islamic radicalism and extremism.

In the same way the first position ("Islamic radicals in Russia and outside its limits") and the second ("Ukrainian fascists Banderovites"), which limitation is connected with their circular isolation on the ninth position ("corruption and crime"), are limited terminal. The direct dependence of these positions characterizes the public opinion as the reflecting influence of corruption of public authorities and organizational structure of the criminal environment on the strengthening of threat for the Russian statehood, proceeding from Islamic, on the one hand, and far-right extremism, on the other hand.

Thus, at the general negative assessment of far-right trends, dominating in the public opinion, and the primary idea of the right-wing radicalism as a threat for the national security of Russia, the public opinion is not alien to the acceptance of its ideologems which, being boundary, express absolutely different ideological concepts of ideological and political trends. It, under the certain circumstances, is capable to do their representatives the "allies" of the right radicals and the participants of political actions of far-right and even extremist character. 


\section{Лumepamypa}

1. Аминов Д.И., Оганян Р.Э. Молодежный экстремизм в России. М.: Academia, 2007, $200 \mathrm{c}$.

2. Бахтин М.М. Фрейдизм. Формальный метод в литературоведении. Марксизм и философия языка. Статьи. М.: Лабиринт, 2000.

3. Игры на идеологической периферии / [С.П. Поцелуев, М.С. Константинов, П.Н. Лукичев и др.]. Ростов-на-Дону: Изд-во ЮНЦ РАН, 2016, 396 с.

4. Константинов М.С. Фашизм: операционализация признаков // Политика и общество. 2014. № 11 (119).

5. Кривопусков В.В. «Русский мир» как ориентир цивилизационной идентификации и социальной интеграции россиян. Ростов н/Д: Фонд науки и образования. 2016. $172 \mathrm{c}$.

6. Крыштановский А.О. Анализ социологических данных с помощью пакета SPSS. М.: ГУ ВШЭ, 2006.

7. Лукичев П.Н. Идеологемы правого радикализма в общественном сознании студентов вузов Ростовской области // Гуманитарий Юга России. 2016. № 6.

8. Переяслова И.Г., Колбачев Е.Б., Перяслова О.Г. Статистика. Ростов на-Дону: Феникс, 2003. 288 с.

9. Поцелуев С.П., Константинов М.С. Современный правый радикализм: проблема идентификации признаков // Политическая концептология: журнал метадисциплинарных исследований. 2014. № 3.

10.Edelman M. Politik als Ritual. Die symbolische Funktion staatlicher Institutionen und politischen Handelns. Frankfurt am Main\&New York: Campus Verlag, 1990.

11.Freeden M. Ideologies and Political Theory: A Conceptual Approach. Oxford: Oxford University Press, 2006.

12. Griffin R. The Nature of Fascism. London\&NewYork: Routledge, 1993.

\section{References}

1. Aminov D.I., Oganian R.E. Molodezhnyi ekstremizm v Rossii [Youth extremism in Russia]. Moscow: Academia, 2007. 200 p. (in Russian).

2. Bakhtin M.M. Freidizm. Formal'nyi metod $v$ literaturovedenii. Marksizm i filosofiia iazyka. Freudianism [The formal method in literary criticism. Marxism and philosophy of language]. Stat'i [Articles]. Moscow: Labirint, 2000 (in Russian).

3. Igry na ideologicheskoi periferii [Games on the ideological periphery] [S.P. Potseluev, M.S. Konstantinov, P.N. Lukichev and others]. Rostov-on-Don: IuNTs RAN, 2016. 396 p. (in Russian).

4. Konstantinov M.S. Fashizm: operatsionalizatsiia priznakov. Politika i obshchestvo. [Fascism: operationalisation of signs. Policy and society]. 2014. No. 11 (119) (in Russian).

5. Krivopuskov V.V. "Russkii mir' kak orientir tsivilizatsionnoi identifikatsii i sotsial'noi integratsii rossiian ["Russian world" as a reference point of civilization identification and social integration of Russians], Rostov-on-Don: Fond nauki i obrazovaniia [Fund of science and education]. 2016. 172 p. (in Russian). 
6. Kryshtanovskii A.O. Analiz sotsiologicheskikh dannykh s pomoshch'iu paketa SPSS [Analysis of sociological data with the help of SPSS package]. Moscow: National university "Higher School of Economics", 2006 (in Russian).

7. Lukichev P.N. Ideologemy pravogo radikalizma $v$ obshchestvennom soznanii studentov vuzov Rostovskoi oblasti. Gumanitarii luga Rossii [ldeologems of the rightwing radicalism in public consciousness of students of higher education institutions of the Rostov region. Humanist of the South of Russia]. 2016. No. 6. (in Russian).

8. Pereiaslova I.G., Kolbachev E.B., Periaslova O.G. Statistika [Statistics]. Rostov-onDon: Feniks. 2003. 288 p. (in Russian).

9. Potseluev S.P., Konstantinov M.S. Sovremennyi pravyi radikalizm: problema identifikatsii priznakov. Politicheskaia kontseptologiia: zhurnal metadistsiplinarnykh issledovanii Modern right-wing radicalism: problem of identification of signs. [Political science of concepts: magazine of metadisciplinary researches]. 2014. No. 3 (in Russian).

10.Edelman M. Politik als Ritual. Die symbolische Funktion staatlicher Institutionen und politischen Handelns. Frankfurt am Main\&New York: Campus Verlag, 1990.

11.Freeden M. Ideologies and Political Theory: A Conceptual Approach. Oxford: Oxford University Press, 2006.

12. Griffin R. The Nature of Fascism. London\&NewYork: Routledge, 1993. 